\title{
Exploratory and confirmatory factor analysis of the Roteiro de Avaliação da Consciência Fonológica, a phonological awareness test
}

\author{
Análise fatorial exploratória e confirmatória \\ do Roteiro de Avaliação da \\ Consciência Fonológica
}

Acácia Aparecida Angeli dos SANTOS 1

Thatiana Helena de LIMA²

\begin{abstract}
The objective of this study is to investigate the evidence of construct validity of a phonological awareness instrument. Exploratory factor analysis was carried out on data collected from 510 elementary and middle school students in 2nd and 6th grades attending two different public schools in the city of São Paulo, Brazil; most were males with mean age of 8.4 years. Confirmatory factor analysis was carried out on data collected from 427 students from other four Brazilian states in the same grades; most were females with mean age of 9.3 years. The instrument used was the Roteiro de Avaliação da Consciência Fonológica, a phonological awareness test. The exploratory factor analysis showed a three-factor solution. As for the confirmatory factor analysis, of the two models tested, the one that indicated better model fit indices was composed of three factors. The model found is adequate for the task carried out in this study. However, more studies should be carried out to further refine the instrument.
\end{abstract}

Keywords: Education, primary and secondary; Phonological awareness; Test validity.

\section{Resumo}

Este estudo propôs estudar a evidência de validade de construto para uma medida de consciência fonológica. Da análise fatorial exploratória, participaram 510 alunos de $2^{\circ}$ a $5^{\circ}$ anos do ensino fundamental de duas escolas públicas do interior paulista, sendo a maioria do sexo masculino, com média de 8,4 anos de idade. Da análise fatorial confirmatória, participaram 427 alunos dos mesmos anos do ensino fundamental, de outros quatro estados brasileiros, sendo a maioria do sexo feminino, com média de 9,3 anos de idade. O instrumento utilizado foi o Roteiro de Avaliação da Consciência Fonológica. Os resultados mostraram que para a análise fatorial exploratória foram formados três fatores, já para a análise fatorial confirmatória, dos dois modelos testados, o que apresentou melhores índices de ajuste foi o composto por três fatores. O modelo encontrado faz jus à atividade realizada, entretanto outros estudos são importantes para refinar ainda mais o instrumento.

Palavras-chave: Ensino fundamental e médio; Consciência fonológica; Validade do teste.

1 Universidade São Francisco, Programa de Pós-Graduação Stricto Sensu em Psicologia. Campinas, SP, Brasil.

2 Universidade Federal da Bahia, Instituto de Psicologia. R. Aristides Novis, 197, Estrada de São Lázaro, 40210-730, Salvador, BA, Brasil. Correspondência para/Correspondence to: T.H. LIMA. E-mail: <thatianahlima@gmail.com>.
} 
Phonological awareness is a meta-linguistic skill related to the recognition of phonological aspects or sound structure of language. The ability to intentionally manipulate word structure, such as to substitute a sound or segment it into smaller units, also refers to phonological awareness (Benítez, Vargas, Hernández, Sánchez, \& García, 2007; Capovilla, Dias, \& Montiel, 2007). Some authors, such as Capovilla et al. (2007), believe that phonological awareness may involve different skills that differ in order of acquisition.

Phonological awareness develops gradually as the child becomes aware that words, syllables, and phonemes are identifiable units (Supple, 1986). Therefore, it can be divided into levels or elements; awareness of "chunks" larger than phonemes, such as rhymes, syllables, alliterations, and words, refers to supraphonemic awareness, while phonemic awareness refers to the specific awareness of a phoneme (Morais, 1995).

There are several studies that address the importance of phonological awareness for the acquisition of reading and writing. According to Frith (1985), among the basic strategies to deal with the written word, the alphabetical strategy is the one in which children need to analyze the graphemes and phonemes for encoding and decoding. Through the phonological reading route, which is developed with this strategy, occurs the conversion of spelling into phonology and vice versa, and thus it is possible that the child can read any new word. The Observatoire National de la Lecture produced a report in 2001 showing that children slowly build a spelling mental lexicon through graphophonemic decoding.

The studies discussed below give examples stressing the importance of phonological awareness for learning to read and write. One of them, carried out by Justino and Barrera (2012), aimed to verify the effectiveness of a phonological awareness intervention in children with significant gaps in literacy skills. Thirty one public school students in 5th-9th grades of both genders and with a mean age of 11.9 years participated in that study. The authors found that the post-test scores were

212 significantly higher than those of the pretest.
Puliezi and Maluf (2012) compared the performance of good and poor readers in different tasks; one of the tasks was phonological awareness, and it aimed at identifying the skills in which they differed. Twenty one first graders completed the instruments. Students who obtained higher scores on reading also obtained higher scores on phonological awareness than those with poor reading performance.

A. Roazzi, Roazzi, C. N. G. Justi, and Justi (2013) also showed that phonological awareness is necessary for literacy achievement. The objective of their study was to identify the relationship between phonological awareness and reading skills. Instruments that assess phonological awareness were administered to 69 private school students starting primary schooling and again one year later. The results showed that the phonological awareness scores predicted reading ability within the same time period and one year later.

Phonological awareness can be assessed by manipulation of segments such as rhyme and alliteration (Cardoso-Martins \& Frith, 1999). This type of evaluation, known as The Oddity Test was first introduced by Bradley and Bryant (1983) and has been widely used ever since. Instruments that involve manipulating sounds of words have been developed to assess phonological awareness (Mota, Santos, Guimarães, \& Conti, 2014).

In Brazil, there are few instruments available to assess phonological awareness in children or instruments with psychometric properties, which could therefore be used to measure the construct discussed in the present study. One test developed for this purpose is the Roteiro de Avaliação da Consciência Fonológica (RACF, Protocol for Phonological Awareness Task), developed by Santos (1996). Their initial experimental study involved 55 preschool students of both genders and mean age of six years and two months attending two public and two private schools. A program for the development of phonological awareness skills was developed, and the results showed positive effects, which were identified after program completion. It was observed that the medium-term effects were maintained in the two experimental groups of the 
public and private schools when the instrument was administered again six months after completion of the research.

Suehiro and Santos (2011) analyzed criterion-related validity evidence based on the external criterion school level and the performance of students in the first four grades of elementary school. A total of 221 students of both genders and mean age of eight and a half years attending a public school in the state of São Paulo participated in their study. All children completed the instrument (RACF). The results showed an increase in the number of correct answers across grades resulting in improvements at higher grades, confirming criterion validity (Suehiro \& Santos, 2011). Similar results were found by Mota et al. (2014), in a study with 217 elementary school students in 2 nd and 4 th grades.

In another study, Suehiro and Santos (2015) found new validity evidence of the RACF by comparing it with the Cloze test, which evaluates reading comprehension; both are considered as related measures. The authors investigated 112 st and 7th grade students of both genders and mean age of 8 years in attending a public school in the state of São Paulo. The results showed that students with higher scores on phonological awareness were also those who had higher scores on reading comprehension. That study corroborates their own previous studies, showing that conscious manipulation of speech sounds is important for reading comprehension achievement.

Nevertheless, an analysis of the internal structure of the RACF has not yet been carried out. Therefore, due to the importance and the need for more validity evidence (content validity), the present study aims to determine the construct validity of the RACF using exploratory and confirmatory factor analysis.

There are two types of factor analysis, exploratory and confirmatory, which have to be adequate for the objectives of the study in which they will be applied. Exploratory Factor Analysis is carried out when little is known about the underlying structure of a set of variables. Confirmatory Factor Analysis is a procedure to test hypotheses about the structure of a set of variables.
This type of analysis is useful for the construction of theories (Hair Jr., Anderson, Tatham, \& Black, 2005).

Exploratory Factor Analysis (EFA) has been one of the most widely used statistical procedures in the development, evaluation, and refinement of psychological instruments (Floyd \& Widaman, 1995). After the completion of the exploratory factor analysis, confirmatory Factor Analysis was carried out to confirm the results of EFA and to determine the psychometric properties of instrument studied.

The Hypothesis tested in the present study is that the RACF items will remain in a single group due to the fact that of all of the items assess the same construct. However, it is worth mentioning that the tasks are different and can have varying degrees of difficulty, a fact that has not yet been explored and is not the objective of this study. There are studies that show the importance of short-term memory for phonological awareness activities (Cardoso, Silva, \& Pereira, 2013; Cárnio, Sá, Jacinto, \& Soares, 2015; Soares, Jacinto, \& Cárnio, 2012; Vieira, 2014); this variable may also influence the activities proposed.

\section{Method}

\section{Exploratory Factor Analysis and participants}

A total of 510 2nd and 6th grade students from two different public schools (located in province of the state of São Paulo) participated in this stage of the present study. Among the participants, $48.0 \%$ were female and $49.1 \%$ were male and $2.9 \%$ of the students did not answer the question about gender. These participants were aged between 6 and 11 years with mean age of 8.4 years $(S D=1.24)$.

\section{Confirmatory Factor Analysis and participants}

A total of 427 2nd and 6th grade students participated in this stage of the present study. These 
students were from public schools of four different Brazilian states, namely Paraná (29.5\%), Mato Grosso (18.7\%), Amazonas (23.9\%), and Bahia (27.9\%). Of the 427 participants, $45.4 \%$ were male and $54.3 \%$ were female, and only one of them did not answer the question about gender. The students were aged between 7 and 13 years with mean age of 9.3 years $(S D=1.20)$.

\section{Instruments}

Identification questions: participants' personal Information, such as name, age, gender, and grade in school was collected and included in the instrument (RACF).

Roteiro para Avaliação da Consciência Fonológica (Santos, 1996): a phonological awareness instrument - This is a screening test composed of three sections of items, each with five items and two examples which aim to evaluate difficulties in identifying a phoneme at the beginning, middle, and end of words. Each item consists of one model word and three other alternative words. For example, if the model word given as a stimulus is "copo" (Brazilian Portuguese), the child should select from among the three possible answers provided, the word that begins with the same sound: cobra, sapo, and lata (Brazilian Portuguese). In this case the word "cobra" is correct. An example using words in English would be: if the model word given is "horse", the child should select from among the following three answers, the word that begins with the same sound: home, snake, and book; in this case the word "home" is correct. In this task, the child receives one point for each correct answer, and the maximum number of points the child can earn is 15 points. The criterion validity of this instrument was previously confirmed when the authors identified that the higher the school grade, the better the results (Suehiro \& Santos, 2011).

\section{Procedures}

The subjects of the present study are part of 214 a larger study which aimed to assess the language skills of elementary and middle school students. One of the purposes was to validate the instrument for the various regions of Brazil without exclusion criteria since all students attending elementary and middle school participated in the study.

The present study was approved by the Research Ethics Committee of the Universidade São Francisco, Itatiba, SP, Brazil (São Francisco University, a Franciscan higher education institution in the state of São Paulo), under the Protocol $n^{\circ}$ 0273.0.142.000-08. The instrument was administered in rooms selected by the school to students whose parents or guardians signed the written informed consent statement. The instrument was individually administered and supervised by undergraduate and graduate (enrolled in masters or doctorate programs) psychology students. These students were properly trained to ensure the instrument would be administered under the same conditions in every school by following specific instructions and guidelines. The total administration time was approximately 15 minutes.

Exploratory factor analysis was carried out using the Statistical Package for the Social Sciences (SPSS). The statistical model was tested using AMOS (Analysis of Moment Structures) 16 and the maximum likelihood estimation method. The model fit was evaluated in a one-factor model and in a three-factor model. In order to identify the model, the metric of latent variables was fixed at mean 0 and standard deviation 1. For the model fit assessment, four fit indices were used, according to the literature recommendations (Byrne, 2001; Schweizer, 2010). The Chi-square index indicates the magnitude of the discrepancy between the observed and expected (fitted) covariance matrices. High chi-square values indicate inadequate fit; however, Chi-square (AMOS lists relative Chi-square as CMIN/DF [Minimum Discrepancy/Degrees of Freedom] - Chi-square/degree of freedom ratio) is affected by the sample size. Therefore, it is recommended to use a Chi-square/df ratio $\left(\chi^{2} / d f\right)$ less than 2, which indicates good fit. The "Comparative Fit Index" (CFI) analyzes the model fit comparing it to the null model (in which all of the variables are uncorrelated). A CFI value greater 
than 0.95 is indicative of good fit. The Root-Square Error of Approximation (RMSEA) fit index is also a measure of discrepancy, but it penalizes model complexity. Root-Square Error of Approximation values less than 0.05 indicate a good fit. Finally, the Standardized Root Mean Square Residual (SRMR) fit index indicates the standardized mean of the residues (a residue is the difference discrepancies between the observed and expected matrices). Standardized Root Mean Square Residual values less than 0.10 are indicative of good fit.

\section{Results}

\section{Exploratory factor analysis}

Initially, the factorability of the correlation matrix of the 15 items of the instrument (RACF) was examined; it was considered to be factorable: Kaiser-Meyer-Olkin $(\mathrm{KMO})=0.82$ and Bartlett's test of sphericity $=\chi^{2}(105)=919.06, p<0.001$. Since the goal was to identify possible latent constructs, EFA was carried using the extraction method Principal Axis Factoring (PAF) and Promax rotation (Fabrigar, Wegener, MacCallum, \& Strahan, 1999). To determine the number of factors to retain, the "eigenvalues greater than 1.00 rule" and the Scree test were used (Laros, 2004).

The results of the EFA indicated three factors with eigenvalue greater than 1.0. The Scree test, shown in Figure 1, confirmed the EFA solution; the

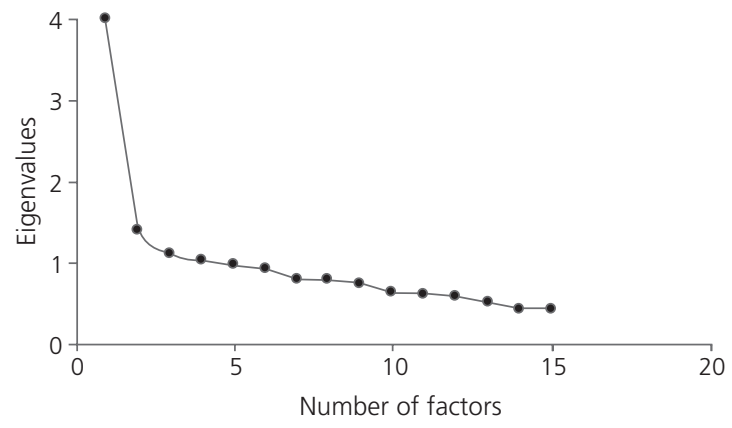

Figure 1. Scree plot for the factors of the instrument studied, Protocol for Phonological Awareness Task (Roteiro de Avaliação da Consciência Fonológica). scree plot shows a substantial drop after the third factor (the first 10 eigenvalues were: 3.35, 1.40, $1.06,0.99,0.98,0.90,0.87,0.83,0.76$, and 0.73 ). These results indicate that three factors were extracted, which explained $38.74 \%$ of the total variance. Table 1 shows these results.

As can be seen from Table 1, the items 8 and 15 did not load on the same factors for which they were intended in the task, and were therefore excluded from subsequent statistical analysis. As expected, factors 1 and 2 grouped items corresponding to the same group of sounds, beginning and end sounds, respectively. The first factor was composed of 5 items with saturations ranging between 0.399 and 0.700 and eigenvalue of 3.35 , explaining $22.32 \%$ of the total variance. Factor 2 was composed of four items with saturations between 0.429 and 0.738 and eigenvalue of 1.40 , explaining $9.35 \%$ of the total variance. Factor 3, composed of middle sound items, had four items, just like factor 2 , with saturations ranging from 0.519 to 0.660 and eigenvalue of 1.06 , explaining $7.07 \%$ of the total variance.

It can be observed that the instrument items did not load on a single factor; it showed that a three-factor solution fits the data the best. The items

Table 1

Distribution of the items by factor in the instrument studied - Protocol for Phonological Awareness Task (Roteiro de Avaliação da Consciência Fonológica)

\begin{tabular}{lccc}
\hline & \multicolumn{3}{c}{ Factors } \\
\cline { 2 - 4 } Items & 1 & 2 & 3 \\
\hline PhAw_1 & 0.697 & & \\
PhAw_2 & 0.649 & & \\
PhAw_3 & 0.659 & & \\
PhAw_4 & 0.700 & & 0.429 \\
PhAw_5 & 0.399 & & 0.738 \\
PhAw_6 & & & \\
PhAw_7 & & & 0.613 \\
PhAw_8 & & 0.483 & \\
PhAw_9 & & & \\
PhAw_10 & & & \\
PhAw_11 & & 0.660 & \\
PhAw_12 & & 0.519 & \\
PhAw_13 & & 0.607 & \\
PhAw_14 & & 0.603 & \\
PhAw_15 & 0.374 & & \\
\hline
\end{tabular}

Note: PhAw: Phonological Awareness. 
were grouped according to the sub-skill measured, i.e., the recognition of the beginning, middle, and ending sounds.

\section{Confirmatory Factor Analysis}

The models were tested in order to find the one that best represents the construct evaluated. The initial hypothesis was that the items formed a single factor; however this was not shown in the exploratory factor analysis. Each sound group (beginning, middle, and ending sounds) formed a factor. Thus, two models were analyzed, a one-factor and a three-factor models, aiming to prove the hypothesis tested in the exploratory analysis, i.e., each "sound" in a factor. The fit indices used in the two models are shown in Table 2.
As can be seen from Table 2, the three-factor model had the best fit indices $\left(\chi^{2} / d f=1.854, C F I=0.901\right.$, RMSEA $=0.045$, and SRMR $=0.0477)$, as proposed in the exploratory factor analysis. The resulting model is shown in Figure 2 below.

Figure 2 shows that the highest correlation $(r=0.43)$ was found between factors 1 (beginning sound) and 2 (ending sound), and the lowest correlation ( $r=0.24$ ) was found between factors 1 (beginning sound) and 3 (middle sound). This result shows that there is common process related to phonological awareness among the factors, but there is a difference between them which may be related to the difficulty of the item or to other variables that may be involved in the assessment such as working memory.

Table 2

Fit indices used in the RACF models

\begin{tabular}{lcccccc}
\hline Model & $\chi^{2}$ & $d f$ & $\chi^{2} / d f$ & CFI & RMSEA & SRMR \\
\hline One-factor model & 234.931 & 90 & 2.610 & 0.785 & 0.061 & 0.0605 \\
Three-factor model & 114.933 & 62 & 1.854 & 0.901 & 0.045 & 0.0477 \\
\hline
\end{tabular}

Note: RACF: Protocol for Phonological Awareness Task (Roteiro de Avaliação da Consciência Fonológica); CFI: Comparative Fit Index; RMSEA: Root-Square Error of Approximation; SRMR: Standardized Root Mean Square Residual.

0.16
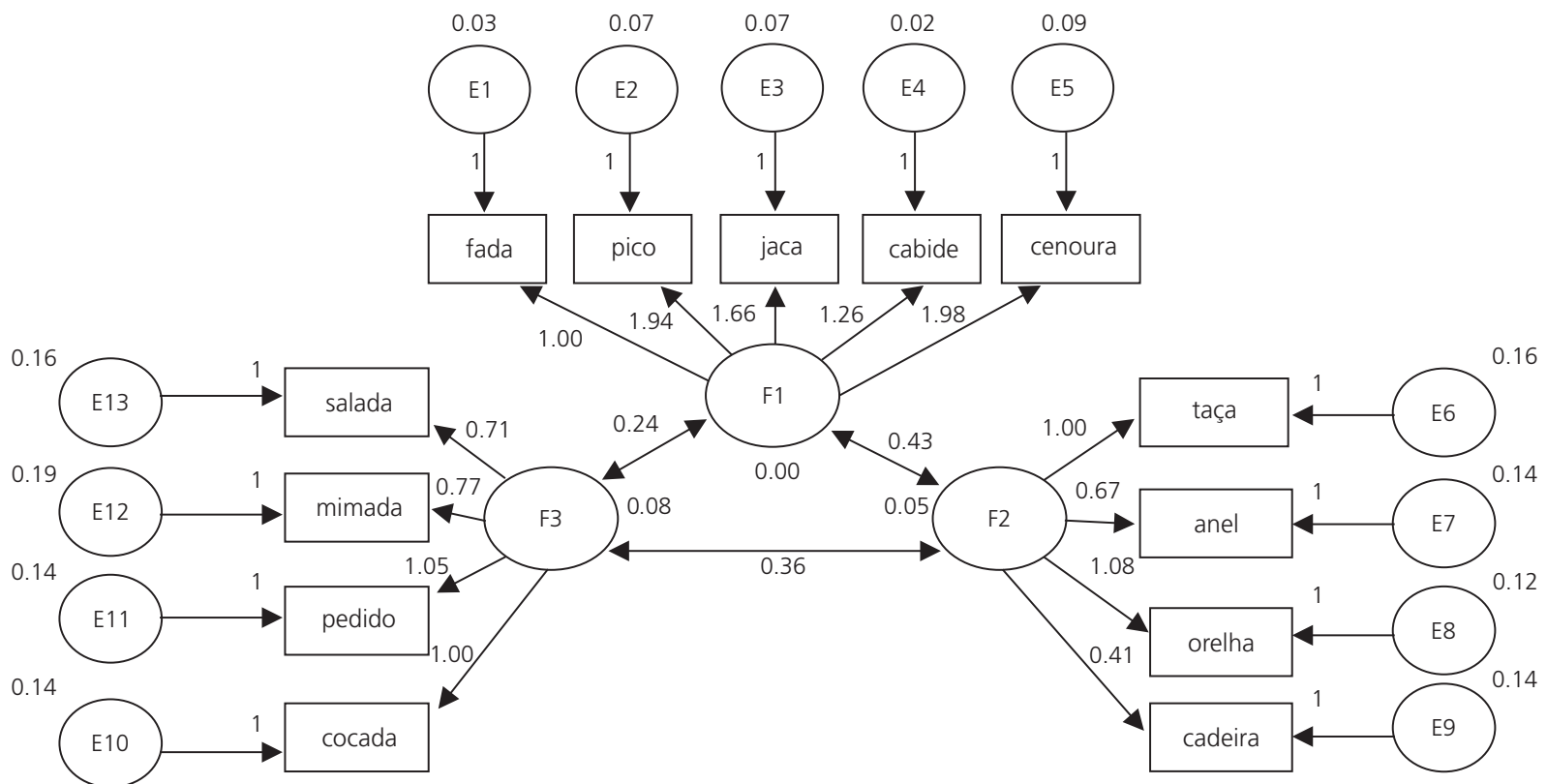

Figure 2. Factorial structure of the instrument studied, Protocol for Phonological Awareness Task (Roteiro de Avaliação da Consciência Fonológica); words given in Brazilian Portuguese. 


\section{Discussion}

The main objective of this study was to investigate evidence of construct validity of the phonological awareness test RACF testing the hypothesis that there is only a single factor in the instrument. A one-factor structure was not found in the instrument, but the fit indices found for the three-factor model have been reported in the literature (Byrne, 2001; Schweizer, 2010). It was found that this model was also possible for the instrument studied since these factors were separated by the differences in the tasks (rhyme, alliteration, and middle sound), showing that this may be related to the difficulty in each factor group or even to other variables that may be necessary to perform the task, such as working memory.

It is important to highlight that there are no studies focusing on providing evidence of the construct validity of the RACF, based on the instrument item analysis. However, evidence of factorial validity of this instrument seems substantial. The three-factor model was considered the most adequate, and it is represented by the factors "beginning sound", "middle sound", and "ending sound". This structure proved to be more feasible than the other structure tested for this measure. Therefore, in order to explain the configuration found in the present study, there are other aspects involved in phonological awareness that should be investigated besides working memory, which has already been reported in other studies (Cardoso et al., 2013; Cárnio et al., 2015; Soares et al., 2012; Vieira, 2014).

It is worth mentioning that the analyses carried out have different purposes. The purpose of exploratory factor analysis is to characterize the correlations between the items and group them into factors; the confirmatory factor analysis bases on the premise that there are factors and they have to be confirmed (Hair Jr. et al., 2005). This shows that, in the present study, one complements the other since the initial hypothesis was that only a single factor would be formed with the instrument items. However, these items were grouped by the task proposed in the test, i.e., three factors were formed, which was confirmed by the second analysis. This finding corroborates Bradley and Bryant (1983) proposal to assess phonological awareness through rhymes, alliterations, or syllables in words.

One limitation of the present study is that there may have been variations in the quality of education delivered by the participant schools since they were chosen based on their proximity to the universities involved in the study. In the absence of this information, such differences could not be managed.

Several studies have highlighted the importance of phonological awareness for reading and writing achievement in literacy development. Both intervention and correlational studies show that phonological awareness facilitates reading acquisition (Justino \& Barrera, 2012; Puliezi \& Maluf, 2012; Roazzi et al., 2013; Suehiro \& Santos, 2015). Another fact that reinforces the importance of phonological awareness assessment is that most elementary and middle school students do not understand fully what they read, and phonological awareness can help minimize this problem (Brasil, 2015).

In summary, RACF can be an important tool to assess children's phonological awareness. Several studies on this instrument have been carried in Brazil showing that it is an adequate test to measure this construct (Mota et al., 2014; Suehiro \& Santos, 2011, 2015). The present study demonstrated the adequacy of this instrument, which is based on the classification "beginning sound" (alliteration), "middle sound", and "ending sound" (rhyme), through the two analyses carried out. Future studies could assess the reliability of the instrument and its items difficulty, and could also investigate the relationship between phonological awareness and working memory. Research on this important language skill can contribute to the understanding of the reading and writing acquisition processes, which is essential in this educational stage.

\section{Contributors}

Both authors contributed equally to manuscript writing and data gathering, analysis, and interpretation. 


\section{References}

Benítez, Y. G., Vargas, G. G., Hernández, A. L., Sánchez, U. D., \& García, A. H. (2007). Habilidades lingüísticas en niños de estrato sociocultural bajo, al iniciar la primaria. Acta Colombiana de Psicología, 10(2), 9-17.

Bradley, L., \& Bryant, P. (1983). Categorizing sounds and learning to read: A causal connection. Nature, 301, 419-521.

Brasil. Ministério da Educação. (2015). Avaliação Nacional de Alfabetização 2014. Recuperado em novembro 15, 2015, de http://portal.mec.gov.br/index.php?option= com_docman\&view=download\&alias=21091 apresentacao-ana-15-pdf\&ltemid=30192

Byrne, B. M. (2001). Structural equation modeling with AMOS: Basic concepts, applications, and programming (2nd ed.). New York: Taylor \& Francis.

Capovilla, A. G. S., Dias, N. M., \& Montiel, J. M. (2007). Desenvolvimento dos componentes da consciência fonológica no ensino fundamental e correlação com nota escolar. Psico-USF, 12(1), 55-64.

Cardoso, A. M. S., Silva, M. M., \& Pereira, M. M. B. (2013). Consciência fonológica e a memória de trabalho de crianças com e sem dificuldades na alfabetização. CoDAS, 25(2), 110-114. https://doi.org/10.1590/S 2317-17822013000200004

Cardoso-Martins, C., \& Frith, U. (1999). Consciência fonológica e habilidade de leitura na Síndrome de Down. Psicologia: Reflexão e Crítica, 12(1), 209-224.

Cárnio, M. S., Sá, B. C. M., Jacinto, L. A., \& Soares, A. J. C. (2015). Memória de curto prazo fonológica e consciência fonológica em escolares do ensino fundamental. CoDAS, 27(5), 458-463. https://doi.org/10. 1590/2317-1782/20152014163

Fabrigar, L. R., Wegener, D. T., MacCallum, R. C., \& Strahan, E. J. (1999). Evaluating the use of exploratory factor analysis in psychological research. Psychological Methods, 4(3), 272-299. https://doi.org/10.1037/ 1082-989X.4.3.272

Floyd, F. J., \& Widaman, K. F. (1995). Factor analysis in the development and refinement of clinical assessment instruments. Psychological Assessment, 7(3), 286-299. https://doi.org/10.1037/1040-3590.7.3.286

Frith, U. (1985). Beneath the surface of developmental dyslexia. In K. Patterson, J. Marshall, \& M. Coltheart (Eds.), Surface dyslexia, neuropsychological and cognitive studies of phonological reading (pp.301-330). London: Erlbaum.

Hair Jr., J. F., Anderson, R. E., Tatham, R. L., \& Black, W. C. (2005). Análise multivariada de dados (5a ed.). Porto Alegre: Bookman.

Justino, M. I. S. V., \& Barrera, S. D. (2012). Efeitos de uma intervenção na abordagem fônica em alunos com dificuldades de alfabetização. Psicologia: Teoria e Pesquisa, 28(4), 399-407.

Laros, J. A. (2004). O uso da análise fatorial: algumas diretrizes para pesquisadores. In L. Pasquali (Org.), Análise fatorial para pesquisadores (pp.147-170). Petrópolis: Vozes.

Morais, J. (1995). A arte de ler. São Paulo: Unesp.

Mota, M. M. P. E., Santos, A. A. A., Guimarães, S. B., \& Conti, C. (2014). Evidências de validade do roteiro de avaliação da consciência fonológica. Estudos e Pesquisas em Psicologia, 14(3), 933-948. https://doi.org/ 10.12957/epp.2014.13892

Puliezi, S., \& Maluf, M. R. (2012). A contribuição da consciência fonológica, memória de trabalho e velocidade de nomeação na aquisição inicial da leitura. Boletim da Academia Paulista de Psicologia, 32(82), 213-227.

Roazzi, A., Roazzi, M. M., Justi, C. N. G., \& Justi, F. R. R. (2013). A relação entre a habilidade de leitura e a consciência fonológica: estudo longitudinal em crianças pré-escolares. Estudos e Pesquisas em Psicologia, 13(2), 420-446. https://doi.org/10.12957/epp. 2013.8417

Santos, A. A. A. (1996). A influência da consciência fonológica na aquisição da leitura e da escrita. In F. F. Sisto, G. C. Oliveira, L. D. T. Fini, M. T. C. C. Souza, \& R. P. Brenelli (Orgs.), Atuação psicopedagógica e aprendizagem escolar (pp.213-247). Petrópolis: Vozes.

Schweizer, M. (2010). Mean-variance hedging and mean-variance. In R. Cont (Org.), Encyclopedia of quantitative finance (pp.1177-1181). Colorado: Wiley.

Soares, A. J. C., Jacinto, L. A., \& Cárnio, M. S. (2012). Memória operacional fonológica em escolares ao final do ciclo I do ensino fundamental. Revista da Sociedade Brasileira de Fonoaudiologia, 17(4), 447-453. https:// doi.org/10.1590/S1516-80342012000400014

Suehiro, A. C. B., \& Santos, A. A. A. (2011). Roteiro de Avaliação de Consciência Fonológica (RACF). Acta Colombiana de Psicología, 14(1), 147-154.

Suehiro, A. C. B., \& Santos, A. A. A. (2015). Compreensão de leitura e consciência fonológica: evidências de validade de suas medidas. Estudos de Psicologia (Campinas), 32(2), 201-211. https://doi.org/10.15 90/ 0103-166X2015000200005

Supple, M. (1986). Reading and articulation. British Journal of Audiology, 20(3), 209-214. https://doi.org/ 10.3109/03005368609079017

Vieira, M. G. (2014). Memória de trabalho e consciência fonológica no desvio fonológico. Letrônica, 7(2), 652-677. https://doi.org/10.15448/1984-4301.2014.2.17672

Received: July 17, 2015

Final version: January 28, 2016

Approved: April 11, 2016 